\title{
Characterization of the genetic locus responsible for the production of ABP-118, a novel bacteriocin produced by the probiotic bacterium Lactobacillus salivarius subsp. salivarius UCC118
}

\author{
Sarah Flynn, ${ }^{1}$ Douwe van Sinderen, ${ }^{2}$ Gerardine M. Thornton, ${ }^{2}$ \\ Helge Holo, ${ }^{3}$ Ingolf F. Nes ${ }^{3}$ and J. Kevin Collins ${ }^{2,4}$
}

Author for correspondence: Douwe van Sinderen. Tel: +35321 4902811. Fax: +353214903101. e-mail: d.vansinderen@ucc.ie

1,2,4 National Food
Biotechnology Centre1,
Department of $^{1}$
Microbiology $^{2}$
Department of
Medicine 4 , University
College Cork, Cork,
Ireland
3 Laboratory of Microbial
Gene Technology,
Agricultural University
of Norway, N-1432 As,
Norway

\section{INTRODUCTION}

Health-promoting bacteria, more generally referred to as probiotics, have been shown to improve the intestinal microbial balance and the properties of the indigenous microflora (Naidu et al., 1999). The intestinal probiotic microflora is believed to promote health directly through its metabolic activities and its physical presence, providing benefits such as the competitive exclusion of medically significant pathogens, stimulation of the

Abbreviations: $A B C, A T P-b i n d i n g ~ c a s s e t t e ; A b p I P$, induction factor; $A U$, activity unit; Bac, bacteriocin production; CFS, cell-free supernatant; LAB, lactic acid bacteria; Lactobacillus salivarius, Lactobacillus salivarius subsp. salivarius.

The GenBank accession number for the sequence reported in this paper is AF408405. immune system, and treatment and neutralization of the side effects of antibiotic therapy (Mattila-Sandholm et al., 1999). Probiotics have been defined as living microorganisms which upon ingestion in adequate numbers exert positive health effects beyond inherent basic nutrition (Guarner \& Schaafsma, 1998). One of the desirable properties of a probiotic strain is the ability to produce antimicrobial substances such as bacteriocins (Mattila-Sandholm et al., 1999).

Bacteriocins are ribosomally synthesized, extracellularly released bioactive peptides or peptide complexes that have a bactericidal or bacteriostatic effect on other (usually closely related) species. In all cases, the producer cell exhibits genetically encoded immunity to the action of its own bacteriocin (Klaenhammer, 1993; Nes et al., 1996). Based on their composition, size, heat stability, mode of action, mechanism of export and inhibitory 
spectrum, bacteriocins produced by lactic acid bacteria (LAB) can be categorized into three or four classes (Klaenhammer, 1993; Nes et al., 1996), of which Class I and Class II are the most prevalent. Class I bacteriocins - the so-called lantibiotics - are small heat-stable peptides that owe their name to the modified amino acids with intramolecular thioether rings, such as lanthionine and $\beta$-methyl-lanthionine, present in their structures. Class II bacteriocins - the small heat-stable non-lantibiotics - are subdivided into three subcategories: IIa, pediocin-like bacteriocins with strong antilisterial effects and a conserved N-terminal YGNGVXC consensus motif within the mature peptide; IIb, bacteriocins whose activity depends on the complementary activity of two peptides; and IIc, bacteriocins whose secretion is sec dependent (Klaenhammer, 1993; Nes et al., 1996).

Most of the bacteriocins identified so far are synthesized as pre-peptides and contain an $\mathrm{N}$-terminal leader sequence, which is removed upon externalization of the bacteriocin (Håvarstein et al., 1995). The synthesis and export of these sec-independent bacteriocins relies upon a minimal genetic structure, generally consisting of four to five clustered genes. Such a bacteriocin gene cluster is composed of one or two structural genes (two in the case of Class IIb bacteriocins), encoding the pre-bacterio$\operatorname{cin}(s)$ and a specific immunity gene, which is located next to the structural gene(s). Furthermore, the cluster includes a gene encoding an ATP-binding cassette (ABC) transporter and a gene encoding an accessory protein, both of which are required for the efficient processing and externalization of the bacteriocin (except in the case of the Class IIc bacteriocins) (Nes et al., 1996). The Nterminal leader sequence of the pre-bacteriocin serves as a recognition signal for the activation of the mature bacteriocin by cleavage of the leader peptide by the proteolytic domain of the transporter protein (Håvarstein et al., 1994, 1995). Additional genes may be present in a bacteriocin gene cluster, such as those regulating bacteriocin production. In several cases, the regulation of bacteriocin production has been shown to be dependent on a so-called three-component regulatory mechanism, consisting of a small induction peptide (which also contains a bacteriocin-like leader peptide that may even act as a bacteriocin), a histidine protein kinase and a response regulator [for reviews see Kleerebezem et al. (1997) and Nes \& Eijsink (1999)]. This three-component regulatory system acts as a quorum-sensing device, coupling co-ordinated bacteriocin production by a particular strain to its cell density.

In this study, we describe the purification and functional characterization of a locus involved in the production of a novel two-component bacteriocin, designated ABP-118, produced by the probiotic strain Lactobacillus salivarius subsp. salivarius (Lactobacillus salivarius) UCC118. We demonstrate that a $10.77 \mathrm{~kb}$ chromosomal region of this strain is sufficient for bacteriocin production and for conferring immunity to Lactobacillus salivarius UCC118 against its own bacteriocin.

\section{METHODS}

Bacterial strains, plasmids and culture conditions. Bacterial strains and plasmids used in this study are listed in Table 1. Lactobacillus salivarius UCC118 was originally isolated from the human gastrointestinal tract, as described previously (Dunne et al., 1999). Lactobacillus strains were cultivated in MRS broth (Oxoid) at $37^{\circ} \mathrm{C}$ under anaerobic (with the Merck Anaerocult A gas pak system) and aerobic conditions. Lactobacillus strains were also cultivated in wort obtained from the University College Cork pilot-plant brewery [the relative density of the wort was $1 \cdot 061$; the wort was made by using a standard mashing procedure (Analytica-EBC 4.5.1)]. Lactococcal strains were routinely propagated at $30^{\circ} \mathrm{C}$ with aeration in M17 broth (Oxoid) containing $0.5 \%(\mathrm{w} / \mathrm{v})$ glucose (GM17). Escherichia coli and Bacillus strains were grown at $37^{\circ} \mathrm{C}$ in Luria-Bertani (LB) broth (Sambrook et al., 1989) and in tryptone soya broth (Oxoid) supplemented with $0.6 \%$ $(\mathrm{w} / \mathrm{v})$ yeast extract $(\mathrm{TSB}+\mathrm{YE})$ with vigorous agitation. Listeria strains were grown at $37^{\circ} \mathrm{C}$ in $\mathrm{TSB}+\mathrm{YE}$ without agitation. The agar media were prepared by adding $1.5 \%$ $(\mathrm{w} / \mathrm{v})$ granulated agar (Difco) to the broth media; overlay agars were prepared by the addition of $0.6 \%(\mathrm{w} / \mathrm{v})$ granulated agar to the broth media. Antibiotics used in the selective media were added at the following concentrations: ampicillin, $100 \mu \mathrm{g} \mathrm{ml}^{-1}$; chloramphenicol, $20 \mu \mathrm{g} \mathrm{m}^{-1}$ (Escherichia coli), $10 \mu \mathrm{g} \mathrm{m}^{-1}$ (Lactobacillus plantarum, Bacillus and Listeria strains) or $5 \mu \mathrm{g} \mathrm{ml}^{-1}$ (Lactococcus lactis); and erythromycin, $6 \mu \mathrm{g} \mathrm{ml}^{-1}$ (Lactobacillus plantarum), $5 \mu \mathrm{g} \mathrm{ml}^{-1}$ (Lactococcus lactis and Listeria strains) or $4 \mu \mathrm{g} \mathrm{ml}^{-1}$ (Bacillus

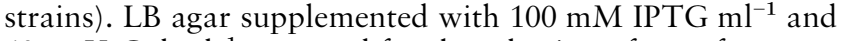
$40 \mu \mathrm{g} \mathrm{X}-\mathrm{Gal} \mathrm{m} \mathrm{l}^{-1}$ was used for the selection of transformants harbouring recombinant pGEM-T or pBluescript plasmids. The chemical reagents listed were obtained from Sigma.

Bacteriocin activity and immunity assays. The bacteriocin activity present in the neutralized ( $\mathrm{pH} \mathrm{6.5)} \mathrm{cell-free} \mathrm{super-}$ natant (CFS) of a producing culture and the activity of purified bacteriocin were determined by critical dilution using the direct, spot-on-lawn assay (Mayr-Harting et al., 1972) or the agar well-diffusion assay (Parente \& Hill, 1992). Activity units (AUs) per millilitre were determined as the inverse of the last dilution at which growth inhibition was still detectable. Bacillus coagulans was used as the standard indicator strain, unless otherwise stated. The level of immunity of Lactobacillus salivarius UCC118 to ABP-118 was tested using concentrated ABP-118, obtained following ammonium sulphate precipitation $(40 \%, \mathrm{w} / \mathrm{v}$, saturation) of the CFS from a culture of Lactobacillus salivarius UCC118 grown to earlystationary phase and the subsequent dialysis of the redissolved protein precipitate as described by O'Keeffe et al. (1999).

Purification of ABP-118. ABP-118 was purified from a Lactobacillus salivarius UCC118 culture that had been grown in MRS broth at $37^{\circ} \mathrm{C}$ until early-stationary phase $\left(\mathrm{OD}_{600}\right.$ $\sim 0 \cdot 8$ ). The purification procedure was essentially that used for the purification of colicin V (Håvarstein et al., 1994), involving ammonium sulphate precipitation followed by sequential hydrophobic interaction (Amberlite XAD-16; Sigma) and cation-exchange chromatography (SP-Sepharose fast-flow; Pharmacia Biotech), with a final purification step by reverse-phase chromatography using a $\mathrm{C}_{2} / \mathrm{C}_{18}$ column (PepRPC HR5/5) on an FPLC system (Pharmacia Biotech). Bacteriocin activity was eluted from the reverse-phase column with a 40 min linear gradient of $30-37 \%$ 2-propanol in aqueous $0 \cdot 1 \%(\mathrm{v} / \mathrm{v})$ trifluoroacetic acid (TFA), followed by a further 5 min gradient of $37-100 \%$-propanol in aqueous 
Table 1. Bacterial strains and plasmids used in this study

\begin{tabular}{|c|c|c|}
\hline Strain/plasmid & Relevant characteristics* & Reference/source $\dagger$ \\
\hline \multicolumn{3}{|l|}{ Lactobacillus } \\
\hline L. salivarius UCC118 & Wild-type producer of ABP-118 & Dunne et al. (1999) \\
\hline L. plantarum NCIMB 8826 & Isolated from human saliva & NCIMB \\
\hline \multicolumn{3}{|c|}{ Lactococcus } \\
\hline L. lactis subsp. lactis IL1403 & Plasmid-free strain containing $l c n C$ and $l c n D$ analogues & Venema et al. (1996) \\
\hline \multicolumn{3}{|c|}{ Bacillus } \\
\hline B. cereus ATCC 14579 & Plasmid-free strain sensitive to ABP-118 & ATCC \\
\hline B. coagulans & Indicator strain sensitive to ABP-118 & UCC \\
\hline \multicolumn{3}{|l|}{ Listeria } \\
\hline L. innocua & Indicator strain sensitive to ABP-118 & UCC \\
\hline L. monocytogenes Scott A & Indicator strain sensitive to $\mathrm{ABP}-118$ & UCC \\
\hline \multicolumn{3}{|l|}{ Escherichia } \\
\hline E. coli JM109 & $\begin{array}{l}\text { recA1 end } A 1 \text { gyrA96 thi hsdR17 }\left(\mathrm{r}_{\mathrm{k}}^{-}, \mathrm{m}_{\mathrm{k}}^{+}\right) \text {relA1 supE44 } \Delta(\text { lac-proAB }) \\
\left(\mathrm{F}^{\prime} \text { traD36 proAB lac } \mathrm{Z} \Delta \mathrm{M} 15\right)\end{array}$ & Promega \\
\hline E. coli XL-1 Blue & $\begin{array}{l}\text { recA1 endA1 gyrA96 thi-1 hsdR17 supE44 relA1 lac ( } \mathrm{F}^{\prime} \text { proAB lacl }{ }^{\mathrm{a}} \mathrm{Z} \Delta \mathrm{M} 15 \\
\left.\text { Tn10; } \text { Tet }^{\mathrm{r}}\right)\end{array}$ & Stratagene \\
\hline \multicolumn{3}{|c|}{ 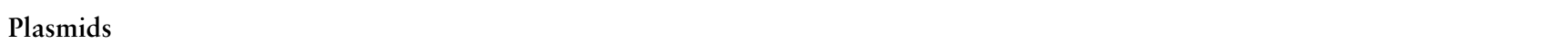 } \\
\hline pGEM-T & $3.0 \mathrm{~kb}$ PCR cloning vector, $\alpha l a c Z ; \mathrm{Ap}^{\mathrm{r}}$ & Promega \\
\hline pUC18 & $3 \cdot 2 \mathrm{~kb}$ cloning vector, $\alpha$ lac $Z ; \mathrm{Ap}^{\mathrm{r}}$ & $\begin{array}{l}\text { Yanisch-Perron et al. } \\
\text { (1985) }\end{array}$ \\
\hline pBluescript $\mathrm{KS}^{+}$ & $3.0 \mathrm{~kb}$ cloning vector, $\alpha \operatorname{lac} Z ; \mathrm{Ap}^{\mathrm{r}}$ & Stratagene \\
\hline pMTL22 & alacZ; Ap ${ }^{\mathrm{r}}$ & Chambers et al. (1988) \\
\hline pIL253 & $4 \cdot 8 \mathrm{~kb}$ high-copy-number vector; $\mathrm{Em}^{\mathrm{r}}$ & Simon \& Chopin (1988) \\
\hline pNZ8048 & Nisin-inducible Escherichia coli-Lactococcus lactis expression vector; $\mathrm{Cm}^{\mathrm{r}}$ & de Ruyter et al. (1996) \\
\hline pNZ44 & Escherichia coli-Lactococcus lactis vector containing P44 promoter; $\mathrm{Cm}^{\mathrm{r}}$ & McGrath et al. (2001) \\
\hline pSF01 & $\begin{array}{l}\text { pGEM-T containing } 80 \text { bp PCR product corresponding to the N-terminal } \\
\text { Abp118 } \alpha \text { peptide }\end{array}$ & This study \\
\hline pSF02 & $\begin{array}{l}\text { pUC18 containing a } 10 \cdot 77 \mathrm{~kb} \text { EcoRI fragment specifying the genetic } \\
\text { information for ABP-118 production }\end{array}$ & This study \\
\hline pSF03 & pBluescript containing the $10.77 \mathrm{~kb} a b p 118$ locus & This study \\
\hline pSF05 & pNZ8048 containing $10 \cdot 77 \mathrm{~kb}$ abp118 locus & This study \\
\hline pSF07 & pNZ8048 containing the $a b p 118$ locus with PvuII deletion in $a b p 118 \alpha$ & This study \\
\hline pSFM1 & pNZ44 abp118 $\alpha$ abp118 $\beta$ abpIM & This study \\
\hline pSFM2 & pNZ44 abp118 $\beta$ abpIM & This study \\
\hline pSFM3 & pNZ44 abpIM & This study \\
\hline pSFM4 & $\mathrm{pNZ44} a b p 118 \alpha$ abpIM & This study \\
\hline pSFMT6 & $\begin{array}{l}\text { pIL253 containing constitutive P27 promoter from Lactococcus lactis phage } \\
\text { Tuc2009 upstream of } a b p T \text { and } a b p D\end{array}$ & This study \\
\hline
\end{tabular}

*Ap ${ }^{r}$, ampicillin resistance; $\mathrm{Em}^{\mathrm{r}}$, erythromycin resistance; $\mathrm{Cm}^{\mathrm{r}}$, chloramphenicol resistance; Tet ${ }^{\mathrm{r}}$, tetracycline resistance. † NCIMB, National Culture of Industrial and Marine Bacteria, Aberdeen, UK; ATCC, American Type Culture Collection, Manassas, VA, USA; UCC, University College Cork strain collection.

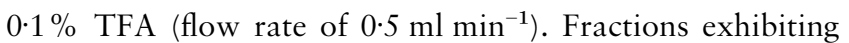
high bacteriocin activity were freeze-dried, dissolved in aqueous $0 \cdot 1 \%$ TFA and re-run on the reverse-phase column to remove any residual impurities. The critical dilution method described above was used to quantify the bacteriocin activity at the various steps of the purification process.

Amino acid sequence analysis and MS. Purified ABP-118 was hydrolysed and analysed on an amino acid analyser, as described by Fykse et al. (1988). The amino acid sequence was determined by Edman degradation with an Applied Biosystems model 477A automatic sequencer equipped with an on-line 120A phenylthiohydantoin amino acid analyser (Cornwell et al., 1988). MS was performed with a Biosystems Voyager-DE STR Biospectrometry Workstation.

DNA isolation. Plasmid DNA was isolated from Escherichia coli strains using the QIAprep Spin Miniprep Kit (Qiagen) and was isolated from Lactococcus lactis strains using the method of Anderson \& McKay (1983). Plasmid DNA from Lactobacillus transformants was isolated by the method of Birnboim \& Doly (1979). Bacillus and Listeria plasmid DNA was isolated using the QIAprep Spin Miniprep Kit, following treatment of a $10 \mathrm{ml}$ culture of mid-exponential growing cells 
with protoplast buffer $(20 \mathrm{mM}$ Tris $/ \mathrm{HCl} ; 5 \mathrm{mM}$ EDTA; $7.5 \mathrm{mM}$ sucrose; $10 \mathrm{mg}$ lysozyme $\mathrm{ml}^{-1}$; $50 \mathrm{U}$ mutanoly$\sin \mathrm{ml}^{-1}$ ) at $37^{\circ} \mathrm{C}$ for $30 \mathrm{~min}$ to effect cell lysis. Total genomic DNA of Lactobacillus salivarius UCC118 was isolated according to the method of Pospiech \& Neumann (1995) with some modifications (outlined below). Lactobacillus salivarius UCC118 was grown in $100 \mathrm{ml}$ MRS supplemented with $40 \mathrm{mM}$ DL-threonine to an $\mathrm{OD}_{600}$ of $\sim 0.6$ and harvested by centrifugation. The pelleted cells were stored overnight at $-20^{\circ} \mathrm{C}$. Cells were lysed using lysozyme $\left(8 \mathrm{mg} \mathrm{ml}^{-1}\right)$ in combination with mutanolysin $\left(50 \mathrm{U} \mathrm{ml}^{-1}\right)$ on ice for $45 \mathrm{~min}$, followed by incubation at $37^{\circ} \mathrm{C}$ for $30 \mathrm{~min}$. Before adding SDS solution, $2 \mathrm{mg}$ proteinase $\mathrm{K} \mathrm{ml}^{-1}$ was added to the lysate and it was incubated at $55^{\circ} \mathrm{C}$ for a further $45 \mathrm{~min}$. The DNA was further purified by $\mathrm{CsCl}$ density-gradient centrifugation (Sambrook et al., 1989).

DNA manipulations. Escherichia coli, Lactococcus lactis, Lactobacillus, Listeria and Bacillus strains were transformed by electroporation by using the methods of Sambrook et al. (1989), Holo \& Nes (1989), Aukurst \& Blom (1992), Park \& Stewart (1990) or Schurter et al. (1989), respectively. All electroporations were carried out with the use of a GenePulser apparatus (Bio-Rad). Restriction enzymes, RNase-free DNase, T4 DNA ligase and Shrimp alkaline phosphatase were used as directed by the manufacturer (Roche Diagnostics). PCR amplification was performed by standard procedures, with BIOTAQ DNA polymerase (Bioline UK) or the Expand High Fidelity PCR System (Roche Diagnostics) and by the use of an Omnigene thermocycler (Hybaid). Thirty cycles of PCR were performed with the following conditions: 1 min at $94^{\circ} \mathrm{C}$, $1 \mathrm{~min}$ at an annealing temperature which ranged from $45^{\circ} \mathrm{C}$ to $55^{\circ} \mathrm{C}$ and an elongation step of $1-3 \mathrm{~min}$ at $72^{\circ} \mathrm{C}$. Oligonucleotide primers for PCR and sequencing were synthesized using an Oligo 1000M DNA Synthesizer (Beckman Instruments). DNA fragments were isolated and purified from agarose gels using the GeneClean II Kit (BIO 101). PCR products were purified using the High Pure PCR Purification Kit (Roche Diagnostics) and cloned into the plasmid vector pGEM-T (Promega). The PCR DIG Probe Synthesis Kit (Roche Diagnostics) was used to generate a non-radioactive hybridization probe complementary to the sequence specifying the N-terminal 26 a sequence of the ABP-118 structural gene. Southern- and colony-blot hybridizations onto Hybond- $\mathrm{N}^{+}$ nylon membranes (Amersham) were performed by standard methods (Sambrook et al., 1989); positive signals were detected by using the DIG Detection Kit (Roche Diagnostics).

DNA sequencing and analysis. DNA sequencing was performed using a 373A automated DNA sequencer (Applied Biosystems) or the CEQ 2000 Dye Terminator Cycle Sequencing Kit (Beckman Coulter), using synthetic oligonucleotides in a primer-walking strategy. Antisense primers were used to confirm the sequence on the complementary strand of DNA. Analyses of the DNA and protein sequences were performed using the DNASTAR software package. Database searches were performed using the BLAST program (Altschul et al., 1997), with the latest release of the non-redundant databases of the NCBI (http://www.ncbi.nlm.nih.gov). The sequence presented here has been submitted to GenBank, where it has been assigned the accession number AF408405.

Plasmid construction and mutational analysis. A number of strategies were used to clone and analyse the genes involved in ABP-118 production and immunity. Plasmid pSF01 contains a DNA fragment corresponding to the $\mathrm{N}$-terminal sequence of the mature Abp118 $\alpha$ peptide cloned into pGEM-T (Promega). Plasmid pSF03 was constructed by cloning a $10.77 \mathrm{~kb}$ chromosomal EcoRI fragment, which contains the genetic information for ABP-118 production, into the EcoRI site of pBluescript. The $10.77 \mathrm{~kb}$ fragment was excised from between the Bam HI and $X h o I$ sites of pBluescript and inserted into the BglII and XhoI sites of pNZ8048, to obtain plasmid pSF05. The restriction of pSF05 with PvuII (the two PvuII sites of pSF05 are located within the $a b p 118 \alpha$ gene) and the subsequent selfligation of the resulting largest DNA fragment allowed the construction of pSF07, containing an in-frame deletion of 72 bp in the $a b p 118 \alpha$ gene. The integrity of this deletion was confirmed by sequence analysis. To investigate the role of $a b p 118 \alpha, a b p 118 \beta$ and $a b p I M$ in ABP-118 production and immunity, pSFM1, pSFM2 and pSFM3 (Table 1) were generated by using high-fidelity PCR and primers which introduced restriction sites to facilitate cloning downstream of the constitutive lactococcal promoter in the expression vector pNZ44. The plasmid pSFM1 contains the two proposed structural genes for ABP-118 activity upstream of the proposed immunity gene, whereas pSFM2 specifies only one of the proposed structural genes, $a b p 118 \beta$, upstream of the proposed immunity gene. The pNZ44 derivative, pSFM3, contains the proposed ABP-118 immunity gene, abpIM, on its own. The SOEing technique (Horton et al., 1990) was used to generate a PCR product encompassing the $a b p 118 \alpha$ structural gene immediately downstream of the abpIM gene, which was subsequently cloned into pNZ44 to generate pSFM4. A PCR fragment corresponding to $a b p T$ and $a b p D$, the proposed genes responsible for ABP-118 transport, was cloned into the NcoI and EcoRI sites of the Escherichia coli vector pMTL22 (Chambers et al., 1988), directly downstream of the constitutive lactococcal P27 promoter from the Lactococcus lactis phage Tuc2009 (D. van Sinderen, unpublished results), which was amplified by PCR using primers containing the restriction sites BglII and NcoI. This construct was restricted with $B g l \mathrm{II}$ and EcoRI; the resulting excised fragment, containing the ABP-118 transport operon cloned in the proper orientation downstream of the constitutive promoter, was subcloned between the BamHI and EcoRI sites of pIL253, generating pSFMT6.

Induction factor synthesis and induction assays. The ABP118 induction factor (AbpIP) was synthesized at MWGBiotech and purified to $>95 \%$ homogeneity by reverse-phase HPLC with an acetonitrile $/ \mathrm{H}_{2} \mathrm{O}$ gradient. The molecular mass was verified by matrix assisted laser desorption ionization time of flight (MALDI-TOF) MS (Voyager-DE; R.P. Perspective Biosystems). To assay for biological activity, a $10^{-3} \mathrm{M}$ stock solution of AbpIP was prepared in sterile distilled water. To lose bacteriocin activity $\left(\mathrm{Bac}^{-}\right)$, a fully grown culture of Lactobacillus salivarius UCC118 was inoculated $(1 \%)$ into wort and allowed to grow anaerobically at $37^{\circ} \mathrm{C}$ until it was turbid. The CFS was assayed for loss of bacteriocin activity against the indicators Listeria innocua and Bacillus coagulans. The resulting $\mathrm{Bac}^{-}$culture was inoculated $(1 \%)$ into wort containing AbpIP at concentrations of $10^{-5}-10^{-14} \mathrm{M}$ and incubated at $37^{\circ} \mathrm{C}$ for $18 \mathrm{~h}$. It was then tested for bacteriocin production.

\section{RESULTS}

\section{Purification of ABP-118}

The purification strategy and results obtained for ABP118 are summarized in Table 2. The final purification step was repeated twice to obtain a pure sample. Passage through a cation-exchange column prior to FPLC decreased the specific activity (Table 2, Fraction III) but resulted in better purification. Upon application of 
Table 2. Purification of ABP-118

All results are representative of three replications.

\begin{tabular}{|c|c|c|c|c|c|c|}
\hline Purification stage (fraction) & Vol. $(\mathrm{ml})$ & Total $A_{280} *$ & $\begin{array}{l}\text { Total activity } \\
\text { (AU) }\end{array}$ & $\begin{array}{l}\text { Specific } \\
\text { activity } \dagger\end{array}$ & $\begin{array}{c}\text { Increase in } \\
\text { specific activity } \\
\text { (fold) }\end{array}$ & Yield $(\%)$ \\
\hline Culture supernatant & 2000 & 30780 & $6.4 \times 10^{6}$ & $2 \cdot 08 \times 10^{2}$ & 1 & 100 \\
\hline Ammonium sulphate precipitate $(\mathrm{I})$ & 100 & 802 & $5 \cdot 1 \times 10^{6}$ & $6 \cdot 38 \times 10^{3}$ & 31 & 80 \\
\hline Hydrophobic interaction (II) & 20 & 31 & $2 \cdot 1 \times 10^{6}$ & $1 \cdot 31 \times 10^{5}$ & 629 & 32 \\
\hline Cation exchange (III) & 20 & $6 \cdot 8$ & $5 \cdot 1 \times 10^{5}$ & $7 \cdot 53 \times 10^{4}$ & 362 & 8 \\
\hline $\mathrm{C}_{2} / \mathrm{C}_{18}$ reverse-phase FPLC $(\mathrm{IV}) \neq$ & 1 & $0 \cdot 26$ & $4 \cdot 1 \times 10^{5}$ & $1.59 \times 10^{6}$ & 7644 & $6 \cdot 4$ \\
\hline
\end{tabular}

Fraction III to the reverse-phase column, ABP-118 activity eluted as a single absorbency peak at $214 \mathrm{~nm}$, corresponding to a concentration of about $100 \%(\mathrm{v} / \mathrm{v})$ 2-propanol (data not shown). The purified bacteriocin was found to have the same inhibitory spectrum as the supernatant of the culture (data not shown).

\section{Amino acid sequence analysis and MS}

The N-terminal sequence of the first 29 aa of the peptide exhibiting inhibitory activity was determined by Edman degradation and generated the following sequence: KRGPNXVGNFLGGLFAGAAAGVPLGPAGI (where $\mathrm{X}$ is an undetermined amino acid). Amino acid compositional analysis did not reveal the presence of unusual residues (data not shown) commonly found in the lantibiotics, such as lanthionine, $\beta$-lanthionine or dehydrated residues. The molecular mass of the purified bacteriocin activity, as determined by MS, was 4096.69 Da, indicating that the bacteriocin activity corresponded to a single peptide composed of 45 or 46 aa.

\section{Identification and cloning of the genetic determinants for ABP-118 production}

Using the degenerate primers 3137 (5'-GGNAAACGNGGNCCNAAC-3') and 3139 (5'-GGGCCCT(A/G)NGGNACNCC-3'), a 78 bp PCR fragment, corresponding to the DNA region encoding the $26 \mathrm{~N}$-terminal amino acids of the mature ABP-118 protein, was amplified from the genomic DNA of Lactobacillus salivarius UCC118, sequenced to confirm its expected sequence and then cloned into pGEM-T, generating pSF01. Total or plasmid DNA preparations isolated from Lactobacillus salivarius UCC118 were digested with a range of restriction enzymes, transferred to a nylon membrane and used in a Southern hybridization experiment employing the insert of pSF01 as a probe. Hybridization signals were observed in specific fragments obtained from total DNA digests, whereas plasmid DNA did not generate hybridizing signals, indicating that the ABP118 structural gene is chromosomally encoded (data not shown). In particular, hybridization of the probe was observed to an approximately $10.77 \mathrm{~kb}$ EcoRI chromosomal DNA fragment. Shotgun cloning of an EcoRI restriction digest of genomic DNA into the EcoRI site of pUC18 was performed. Two Escherichia coli transformants were shown, by colony hybridization, to harbour a recombinant plasmid containing the $10.77 \mathrm{~kb}$ EcoRI fragment; one of these, designated pSF02, was retained for sequence analysis.

\section{Heterologous expression of ABP-118}

The $10.77 \mathrm{~kb}$ bacteriocin-encoding chromosomal fragment of Lactobacillus salivarius UCC118 was cloned into the high-copy-number vector pNZ8048 to generate pSF05, using Escherichia coli as the intermediate host. The resulting plasmid was introduced into a number of bacterial species which were then tested for their ability to produce ABP-118. Plasmid pSF05 conferred Lactobacillus plantarum NCIMB 8826, Lactococcus lactis IL1403 and Bacillus cereus ATCC 14579 with the ability to produce ABP-118 (Fig. 1). Overnight cultures of the transformants produced lower levels of bacteriocin than wild-type Lactobacillus salivarius UCC118. In addition, when pSF07, a derivative of pSF05 encoding the entire ABP-118 operon but carrying an in-frame deletion in the $a b p 118 \alpha$ structural gene (see below), was introduced into Lactobacillus plantarum NCIMB 8826 and Lactococcus lactis IL1403 the resulting transformants failed to produce bacteriocin (data not shown). Thus, deletion of one of the ABP-118 structural genes results in the loss of bacteriocin production.

\section{Sequence analysis of the abp118 gene cluster}

The complete nucleotide sequence of the $10.77 \mathrm{~kb}$ EcoRI fragment was determined by a primer-walking strategy, the analysis of which showed that the fragment consisted of $10769 \mathrm{bp}$ and revealed the presence of 16 complete 


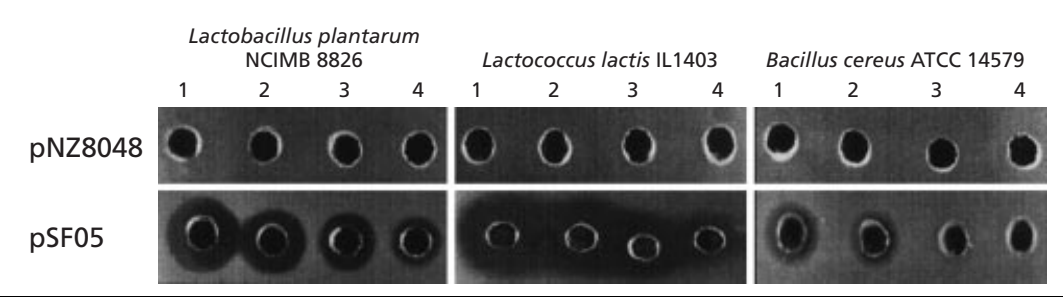

Fig. 1. Inhibitory activity of a twofold serial dilution of ABP-118 secreted by Lactobacillus plantarum NCIMB 8826, Lactococcus lactis IL1403 or Bacillus cereus ATCC 14579, containing either the control plasmid pNZ8048 (upper panel) or pSF05 (lower panel). Bacillus coagulans was used as the indicator strain. Numbers above the wells correspond to the CFS dilution in each well. 1, Undiluted CFS; $2,1: 2$ dilution of CFS; 3 , $1: 4$ dilution of CFS; $4,1: 8$ dilution of CFS.

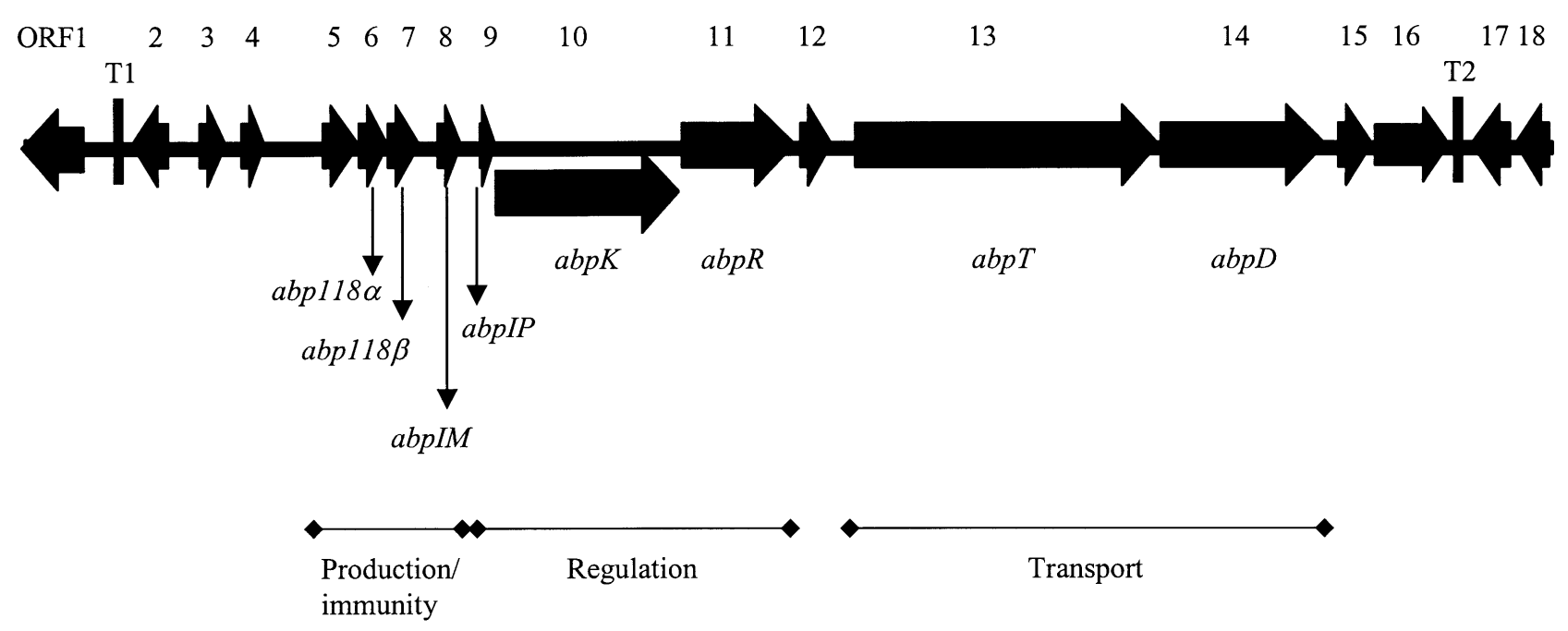

Fig. 2. Graphic illustration of the abp118 locus showing 18 potential ORFs (indicated by arrows). ORFs with a deduced function in the production and secretion of active ABP-118 are denoted by the prefix abp (see Results for explanation). The presence of putative transcriptional terminators (T1 and T2) is indicated by vertical solid bars. Sections of the abp 118 locus assumed to be dedicated to production/immunity, regulation and transport are indicated.

putative ORFs and two incomplete ORFs (Fig. 2; ORFs were numbered $1-18$, but some were re-named if a function could be assigned to their encoded products). The ORFs were identified based on the adopted criteria that an ORF consists of at least 35 codons preceded by a potential Shine-Dalgarno sequence at an appropriate distance $(6-15 \mathrm{bp})$ from one of the commonly used initiation codons (AUG, UUG, GUG) (Harley \& Reynolds, 1987). ORFs 3-16 were all oriented in the same direction. ORF1 and ORF2 (located upstream of ORFs 3-16) and ORF17 and ORF18 (located downstream of ORFs 3-16) were oriented in the opposite direction (Fig. 2). ORF4 appeared to employ a GUG translation initiation codon, whereas ORF11 $(a b p R)$, ORF13 $(a b p T)$, ORF15 and ORF16 were assumed to initiate translation from a UUG start codon. All of the remaining ORFs appeared to use an AUG initiation codon. A pair of short direct repeats with a single mismatch were located in the non-coding region between ORF4 and ORF5 [CTTATAGGG(12nt)CTTCTAGGG]. Inverted repeats typical of $r$ ho-independent transcription-termination signals (Tinoco et al., 1973) were found one nucleotide downstream of ORF2 (T1) and $35 \mathrm{bp}$ downstream of ORF16 (T2), respectively (Fig. 2).

\section{Analysis of the gene products encoded by the abp118 locus}

The primary structures of the deduced products of ORFs 3, 4, 5, 6, 7 and 9 (Table 3) all resembled Class II bacteriocin precursors, which are typically small, cationic, bacteriocin-like peptides containing double-glycinetype leaders and having relatively high pI values (Håvarstein et al., 1994; Nes et al., 1996). The leaders of ORF3, 6, 7 and 9 conformed closely to the consensus leader sequence proposed by Nes et al. (1996), having hydrophobic residues present at positions $-4,-7$, -12 and -15 and hydrophilic residues at positions -8 , -10 and -11 . ORF4 and ORF5 only possessed the consensus amino acids at positions $-4,-10,-11$ and -12 (Table 3 ).

Based on the N-terminal-amino-acid sequencing results, the gene encoding ABP-118 activity, designated $a b p 118 \alpha$, corresponded to ORF6 (Fig. 2). No noticeable difference was observed between the calculated and experimentally determined molecular mass of the mature Abp118 $\alpha$ product, indicating the absence of any major posttranslational modifications. Both abp118 $\alpha$ and ORF7 (designated $a b p 118 \beta$ ), located directly downstream of $a b p 118 \alpha$, exhibited significant sequence similarity to 
Table 3. Pre-peptides of the abp118 locus containing double-glycine leader sequences

\begin{tabular}{|c|c|c|c|c|c|c|}
\hline \multirow[t]{2}{*}{ Protein } & \multicolumn{2}{|r|}{ Amino acid sequence of pre-peptides ${ }^{*}$} & \multicolumn{2}{|c|}{ Pre-peptide } & \multicolumn{2}{|c|}{ Mature peptide } \\
\hline & $\downarrow$ & & $\begin{array}{l}\text { Size } \\
\text { (aa) }\end{array}$ & $\begin{array}{c}\mathrm{pI} \\
\text { Value }\end{array}$ & $\begin{array}{l}\text { Size } \\
\text { (aa) }\end{array}$ & $\begin{array}{c}\mathrm{pI} \\
\text { Value }\end{array}$ \\
\hline ORF3 & MNNNFIQVDKKELAHIIGG & RNSYDYIDSGQFGYDIGCTIANTIFFKRLRHSNQNICS & 57 & $8 \cdot 00$ & 38 & $8 \cdot 00$ \\
\hline ORF4 & VLKKLWNIWLDGG & LIRGRKRYVIIPIIFAIFLPLSMWLSDNEGMSYLDYI & 50 & $9 \cdot 37$ & 37 & $8 \cdot 70$ \\
\hline ORF5 & MLKKLWETWLDGG & $\begin{array}{l}\text { FIRGKKRYVIAPVIWALLIPLGIWLFGNEEMSYLDYIQTPKMIIVTIFCLVGGSTLLY } \\
\text { LLDTAMKVNKHMKG }\end{array}$ & 85 & $9 \cdot 37$ & 72 & $9 \cdot 47$ \\
\hline ORF6 (Abp118 $\alpha$ ) & MMKEFTVLTECELAKVDGG & KRGPNCVGNFLGGLFAGAAAGVPLGPAGIVGGANLGMVGGALTCL & 64 & $6 \cdot 32$ & 45 & $8 \cdot 63$ \\
\hline ORF7 (Abp118 $\beta)$ & MKNLDKRFTIMTEDNLASVNGG & KNGYGGSGNR WVHCGAGIVGGALIGAIGGPWSAVAGGISGGFTSCR & 68 & $9 \cdot 13$ & 46 & $9 \cdot 31$ \\
\hline ORF9 (AbpIP) & MKFEVLTEKKLQKIAGG & ATKKGGFKRWQCIFTFFGVCK & 38 & $10 \cdot 01$ & 21 & $10 \cdot 03$ \\
\hline Consensus† & $-\mathrm{xO}-\mathrm{OO} \mathrm{x}--\mathrm{x}-\mathrm{GG}$ & & & & & \\
\hline
\end{tabular}

* $\mathrm{x}$, Hydrophobic residue; $\mathrm{O}$, hydrophilic residue. The arrow indicates the conserved cleavage site.

† Suggested consensus sequence (Nes et al., 1996).

Table 4. Similarities observed for the proteins specified by the identified ORFs of the abp118 gene cluster to their homologues

Only the best matches are shown. The $P$-values were derived from the TBLAsTP score and represent the probability that the observed similarity had occurred by chance. Low $P$-values indicate a high probability of two proteins being structurally related.

\begin{tabular}{|c|c|c|c|c|c|}
\hline \multirow[t]{2}{*}{ ORF (gene) } & \multirow[t]{2}{*}{ Size (aa) } & \multicolumn{4}{|c|}{ Homologue } \\
\hline & & Comment & $P$-value & Match $(\%)^{*}$ & Reference \\
\hline ORF1 & 150 & Accessory transport protein, brochocin-C system & $0 \cdot 30$ & $12(158)$ & McCormick et al. (1998) \\
\hline ORF2 & 87 & No homologues & & & \\
\hline ORF3 & 57 & Presalivaricin B of Lactobacillus salivarius M6 & $8 \times 10^{-28}$ & $98(57)$ & CAB63109† \\
\hline ORF4 & 50 & No homologues & & & \\
\hline ORF5 & 85 & No homologues & & & \\
\hline ORF6 $(a b p 118 \alpha)$ & 64 & $\begin{array}{l}\text { BlpJ, auto-induced peptide of Streptococcus } \\
\text { pneumoniae }\end{array}$ & $1 \times 10^{-4}$ & $29(89)$ & de Saizieu et al. (2000) \\
\hline ORF7 $(a b p 118 \beta)$ & 68 & Plantaricin $1.25 \beta$ of Lactobacillus plantarum & $8 \times 10^{-3}$ & $27(69)$ & Ehrmann et al. (2000) \\
\hline ORF8 (abpIM) & 55 & No homologues & & & \\
\hline ORF9 $(a b p I P)$ & 38 & $\begin{array}{l}\text { Competence pheromone of Streptococcus } \\
\text { gordonii }\end{array}$ & $2 \cdot 2$ & $20(50)$ & Håvarstein et al. (1996) \\
\hline ORF10 $(a b p K)$ & 429 & Histidine kinase, carnobacteriocin A system & $1 \times 10^{-46}$ & $32(425)$ & Franz et al. (2000) \\
\hline ORF11 $(a b p R)$ & 264 & Response regulator, carnobacteriocin A system & $5 \times 10^{-36}$ & $38(254)$ & Franz et al. (2000) \\
\hline ORF12 & 79 & No homologues & & & \\
\hline ORF13 $(a b p T)$ & 719 & ABC transporter, plantaricin A system & $0 \cdot 0$ & $69(716)$ & Diep et al. (1994) \\
\hline ORF14 $(a b p D)$ & 384 & Accessory transport protein, sakacin A system & $1 \times 10^{-82}$ & $40(461)$ & Axelsson \& Holck (1995) \\
\hline ORF15 & 76 & No homologues & & & \\
\hline ORF16 & 174 & No homologues & & & \\
\hline ORF17 & 88 & No homologues & & & \\
\hline ORF18 & 80 & No homologues & & & \\
\hline
\end{tabular}

* The number of amino acids over which the percentage match was determined is shown in parentheses.

† Accession number of sequence submitted directly to EMBL Database.

each other as well as to a number of putative Class II pre-bacteriocin peptides (Table 4). Some of these prebacteriocin peptides correspond to one member of a Class IIb two-component bacteriocin. This similarity, which was particularly pronounced in the N-terminal region of these proteins, was due mainly to the conserved residues in the leader sequence, common to most Class II pre-bacteriocins, whereas the mature peptides showed limited similarity to any previously described bacterio- cin. Abp118 $\beta$ was found to constitute the second peptide of a two-component bacteriocin (see below). Abp118 $\alpha$ and $\mathrm{Abp} 118 \beta$ had a high proportion of glycine residues (28.9 and $32.6 \%$, respectively) spread evenly along their entire length; this appears to be a common feature of Class II bacteriocins (Klaenhammer, 1993), probably allowing these peptides a high degree of conformational freedom (Ennahar et al., 2000). ORF8, designated abpIM and encoding immunity to the antimicrobial 

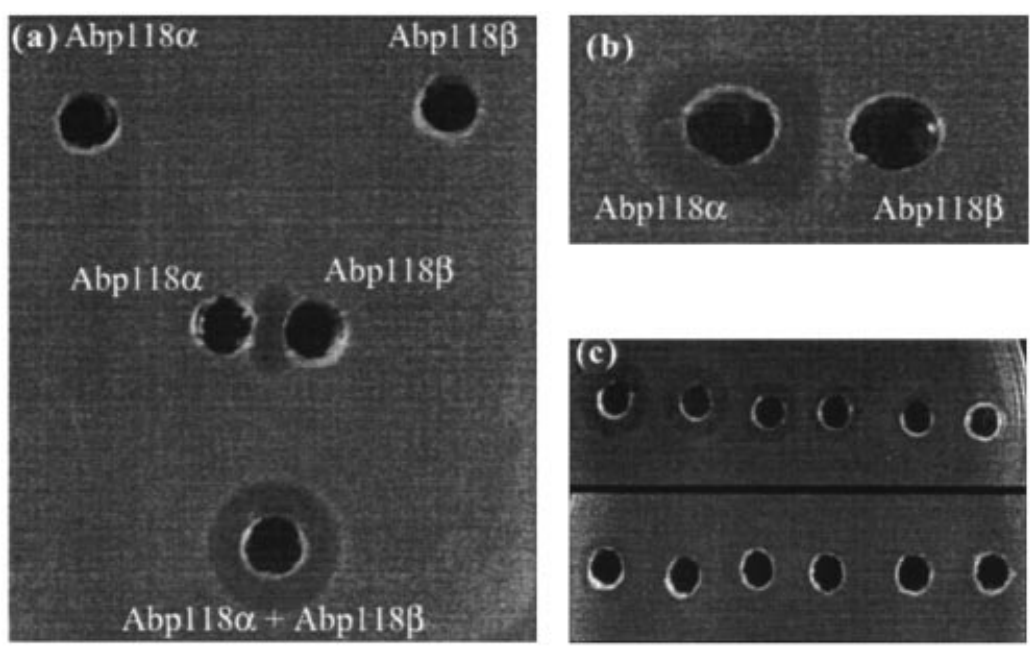

Fig. 3. (a) Bacteriocin activity and extracellular complementation of the Abp $118 \alpha$ and Abp $118 \beta$ peptides. CFS $(25 \mu \mathrm{l})$ of Lactobacillus plantarum NCIMB 8826 containing pSFM4 (Abp118 $\alpha)$ and CFS $(25 \mu \mathrm{l})$ Lactobacillus plantarum NCIMB 8826 containing pSFM2 (Abp118 $\beta$ ) was added to the wells in plates seeded with the ABP-118-sensitive indicator Listeria innocua. CFS $(25 \mu \mathrm{l})$ from each culture was mixed and then added to the well labelled Abp118 $\alpha+$ Abp $118 \beta$. (b) 'Concentrated CFS' $(25 \mu \mathrm{l})$ of Lactobacillus plantarum NCIMB 8826 containing pSFM4 (Abp118 $\alpha$ ) and 'concentrated CFS' $(25 \mu \mathrm{l})$ of Lactobacillus plantarum NCIMB 8826 containing pSFM2 (Abp118 $\beta$ ) were added to adjacent wells in plates seeded with the ABP-118-sensitive indicator Listeria innocua. (c) Sensitivity of Listeria monocytogenes ScottA containing pNZ44 (upper panel) and Listeria monocytogenes ScottA containing pSFM3 (lower panel) to a twofold serial dilution of concentrated ABP-118 (51600 $\mathrm{AU} \mathrm{ml}^{-1}$ ).

activities of the Lactobacillus salivarius UCC118 culture, was located immediately downstream of $a b p 118 \alpha$ and $a b p 118 \beta$ (see below). The deduced protein of ORF3 was nearly identical to the antibacterial peptide precursor presalivaricin B (accession no. CAB63109) (Table 4), differing by only one amino acid at residue 42 . The deduced product of ORF4 was very similar over its entire length to the peptide product of ORF5, which extended for another 35 aa (Table 3 ).

The proteins encoded by ORF9 (designated abpIP), ORF10 (designated $a b p K$ ) and ORF11 (designated $a b p R$ ) exhibited significant sequence similarity to a small, cationic competence pheromone with a doubleglycine-type leader, to histidine protein kinase and to response regulator proteins, respectively (Table 4). These three associated genes therefore seemed to represent a so-called three-component regulatory system, similar to those involved in the control of several Class II bacteriocins (Kleerebezem et al., 1997; Nes \& Eijsink, 1999; see below).

The protein products of the adjacent downstream positioned genes ORF13 and ORF14 exhibited high similarity to ABC-transporter and accessory proteins, and these genes were designated as abpT and $a b p D$, respectively (Table 4). It is well established that the secretion of bacteriocin peptides possessing a doubleglycine-type leader is mediated by a dedicated transmembrane translocator belonging to the $\mathrm{HlyB} \mathrm{ABC}$ transporter superfamily and an accessory protein (Håvarstein et al., 1995; Nes et al., 1996).

\section{ABP-118 is composed of two peptides}

To establish whether both $a b p 118 \alpha$ and $a b p 118 \beta$ were essential for bacteriocin ABP-118 production, abp118 $\alpha$ and $a b p 118 \beta$ were cloned both separately and in combination upstream of an intact abpIM immunity gene (see below), under the control of a constitutive lactococcal promoter in the expression vector pNZ44. The resulting transformants were called pSFM1, pSFM2 and pSFM4 (Table 1). Subsequently, pSFM1was introduced into Lactobacillus plantarum NCIMB 8826 with and without the construct pSFMT6, encoding the putative ABP-118 transport and processing genes abpT and $a b p D$, which were also under the control of a constitutive lactococcal promoter. Only Lactobacillus plantarum NCIMB 8826 transformants containing both pSFM1 and pSFMT6 were capable of producing antimicrobial activity. The inhibition observed against the indicator strain was eliminated when the CFSs of these transformants were treated with $50 \mu \mathrm{g}$ proteinase $\mathrm{K} \mathrm{ml}^{-1}$, confirming the expected proteinaceous nature of the inhibitory compound. This implied that $a b p T$ and $a b p D$ were necessary for the production of active ABP118 in the CFS of a heterologous strain, and it was assumed that these genes encode the dedicated transport and processing functions.

Lactobacillus plantarum NCIMB 8826 clones containing either pSFM2 or pSFM4 in conjunction with pSFMT6 were assayed for inhibitory activity by the agar welldiffusion assay against the indicator Listeria innocua (Fig. 3). No zone of inhibition was observed surrounding the wells containing the CFSs of either the pSFM2 or the pSFM4 transformants. However, when the CFSs of each transformant type were placed in wells adjacent to each other, a zone of enhanced inhibition was observed between the wells (Fig. 3a). The inhibitory activity of the CFSs of both transformant types was concentrated 200fold by ammonium sulphate precipitation, resuspension and dialysis (see Methods). When the 'concentrated CFSs' from both transformant types were assayed for inhibitory activity, it was found that pSFM4 transfor- 
mants possessed antimicrobial activity, whereas none was associated with the concentrated CFS of pSFM2 transformants (Fig. 3b). The strongest zone of inhibition was observed between the wells, indicating that the concentrated CFS of pSFM2 transformants retained its ability to enhance the intrinsic inhibitory activity associated with the concentrated CFS of pSFM4 transformants (Fig. 3b). Enhancement of the antibacterial activity in the CFS of transformants containing either pSFM2 or pSFM4 with the CFS of transformants containing pNZ44 as a control was not observed (data not shown).

\section{ORF8 represents the gene involved in conferring immunity to ABP-118}

The assumption that ORF8, designated here as abpIM and located downstream of $a b p 118 \beta$, encoded immunity was largely based on the fact that in many bacteriocinencoding gene clusters the immunity gene is located immediately downstream of the structural gene(s), and that such immunity-conferring proteins are hydrophobic (Nes et al., 1996). An expression clone, pSFM3, containing only abpIM was constructed to confirm the role of this gene in immunity to ABP-118. Plasmid pSFM3 was introduced into Listeria monocytogenes ScottA, which is sensitive to ABP-118, and this strain was subsequently used as an indicator. Listeria transformants of pSFM3 were immune to 21600 AU ABP$118 \mathrm{ml}^{-1}$, although they were not completely immune to ABP-118 at the highest concentration (51200 AU ABP$118 \mathrm{ml}^{-1}$ ) (Fig. 3c). Thus, the insert on pSFM3 is capable of conferring ABP-118 immunity to a previously sensitive strain.

\section{Bacteriocin production is inducible in Lactobacillus salivarius UCC118}

Spontaneous loss of bacteriocin production was not observed when standard cultures of Lactobacillus salivarius UCC118 were diluted $10^{-6}$ times or more in MRS medium, as has been observed for many three-component regulated Class II bacteriocin-producing bacteria (Nes \& Eijsink, 1999). However, production of ABP-118 was abolished when Lactobacillus salivarius UCC118 was grown in wort. Once Lactobacillus salivarius UCC118 had lost the ability to produce bacteriocin $\left(\mathrm{Bac}^{-}\right)$, subcultures from it continued to be $\mathrm{Bac}^{-}$when grown in wort. The addition of sterile CFS from a $\mathrm{Bac}^{+}$ culture of Lactobacillus salivarius UCC118 induced bacteriocin production, whereas CFS derived from a $\mathrm{Bac}^{-}$culture did not. The inducing component was lost after treatment of the CFS with proteinase $\mathrm{K}$, indicating that the culture contained a protein component that was indispensable for maintaining bacteriocin production. To determine whether the product of abpIP was the induction factor for ABP-118 production, the chemically synthesized mature peptide (AbpIP) was used to induce bacteriocin production in a $\mathrm{Bac}^{-}$culture of Lactobacillus salivarius UCC118 grown in wort. Addition of AbpIP at concentrations above $10^{-10} \mathrm{M}$ restored bacteriocin pro-

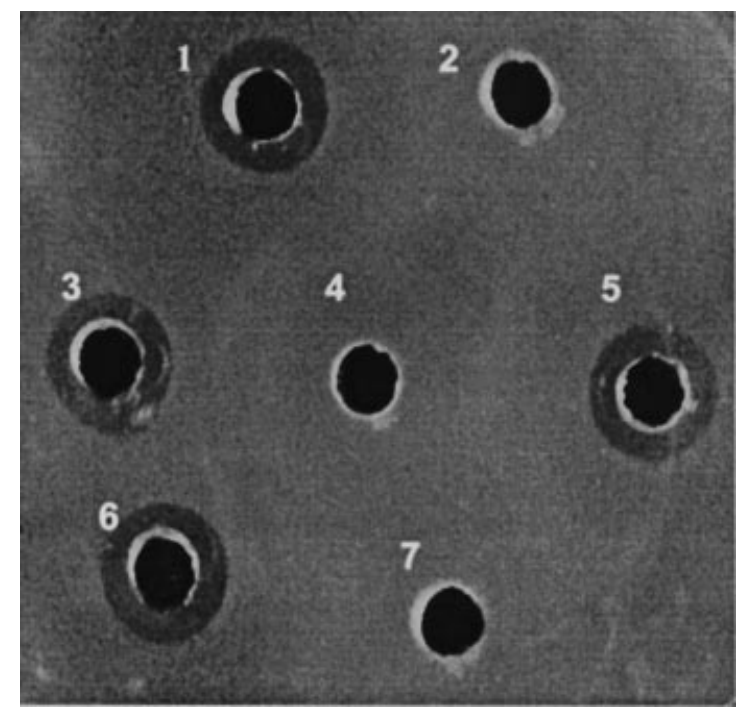

Fig. 4. Inhibitory activity of $A B P-118$ against the indicator Bacillus coagulans. Inhibitory activity of ABP-118 in: 1, the CFS of wild-type Lactobacillus salivarius UCC118; 2, a $\mathrm{Bac}^{-}$derivative of Lactobacillus salivarius UCC118 subcultured in wort; 3, a $\mathrm{Bac}^{-}$derivative of Lactobacillus salivarius UCC118 subcultured in wort containing $20 \mu \mathrm{l}$ of CFS from a $\mathrm{Bac}^{+}$culture of Lactobacillus salivarius UCC118; 4, a $\mathrm{Bac}^{-}$derivative of Lactobacillus salivarius UCC118 subcultured in wort containing $20 \mu \mathrm{l}$ of CFS from a Bac culture of Lactobacillus salivarius UCC118 treated with proteinase $\mathrm{K}$; 5 , a $\mathrm{Bac}^{-}$derivative of Lactobacillus salivarius UCC118 subcultured in MRS; 6 , a $\mathrm{Bac}^{-}$ derivative of Lactobacillus salivarius UCC118 subcultured in wort containing $10^{-6} \mathrm{M}$ AbplP; and 7, a $\mathrm{Bac}^{-}$derivative of Lactobacillus salivarius UCC118 subcultured in wort containing $10^{-6} \mathrm{M}$ AbplP treated with proteinase $\mathrm{K}$.

duction (Fig. 4). When inoculated into wort without AbpIP, the $\mathrm{Bac}^{-}$culture failed to produce bacteriocin and served as a negative control. Proteinase K-treated AbpIP did not induce bacteriocin production, demonstrating that the observed induction was AbpIP specific (Fig. 4). In all cases, whether bacteriocin production was switched on or off following growth in wort, subsequent subculturing into MRS broth resulted in bacteriocin-producing cultures.

\section{DISCUSSION}

This paper describes the identification and genetic analysis of a novel chromosomal locus responsible for the production of a two-component bacteriocin, ABP118, from the probiotic bacterium Lactobacillus salivarius UCC118, which was originally isolated from a human intestinal tract (Dunne et al., 1999). To our knowledge, this is the first published report on the genetic characterization of a bacteriocin locus from a human-derived probiotic strain. ABP-118 is an intriguing broad-spectrum antimicrobial, since it is capable of inhibiting a number of food-borne and medically significant pathogens, including Bacillus, Listeria, Enterococcus and Staphylococcus species, without an apparent antagonistic activity towards related LAB 
strains, with the exception of Lactobacillus fermentum KLD (Dunne et al., 1999). In many cases, bacteriocins produced by LAB inhibit species that are closely related to the producing strain (Marciset et al., 1997).

Our results indicate that the antimicrobial activity arises from the complementary action of two closely related, small, unmodified cationic and hydrophobic peptides, termed Abp118 $\alpha$ and Abp118 $\beta$. The Abp118 $\alpha$ peptide possesses inhibitory activity when concentrated, and this activity is enhanced by the presence of the Abp118 $\beta$ peptide, which on its own has no associated bacteriocin activity. This makes ABP-118 a member of the Class IIb bacteriocins. In some two-peptide systems, including lactococcin $\mathrm{G}$ and brochocin-C, both peptides are needed for activity (Nissen-Meyer et al., 1992; McCormick et al., 1998). In others, such as lacticin F and thermophilin 13, one or both peptides exhibit low but measurable inhibitory activity on their own, but the combined action of both peptides enhances the activity much more than the additive effect of the peptides acting independently (Allison et al., 1994; Marciset et al., 1997).

The genes responsible for ABP-118 production were located on a chromosomally derived $10.77 \mathrm{~kb}$ DNA fragment, and this locus was sufficient to support the heterologous expression of active antimicrobial activity. The organization of the (putative) genes required for ABP-118 production, secretion and regulation is similar to that of other Class II bacteriocin gene clusters (Nes et al., 1996). The adjacent genetic elements abp118 $\alpha$, $a b p 118 \beta$ and $a b p I M$ were identified as the structural gene, the enhancer gene and the putative immunity gene, respectively, for ABP-118. When expressed in Listeria monocytogenes ScottA, abpIM conferred only partial immunity to the highest bacteriocin level used and this partial immune phenotype may be due to lower levels of transcription of abpIM under the control of a lactococcal promoter in this heterologous host.

ABP-118 production appears to be controlled by a socalled three-component quorum-sensing regulatory system consisting of AbpIP, AbpK and AbpR (Brurberg et al., 1997; Diep et al., 2000; Kleerebezem et al., 1997; Nes \& Eijsink, 1999). In a situation similar to that observed for sakacin A production by Lactobacillus sakei LTH673, Lactobacillus salivarius UCC118 does not lose the $\mathrm{Bac}^{+}$phenotype upon extreme dilution of the culture, a strategy used successfully for obtaining a $\mathrm{Bac}^{-}$ phenotype for other bacteriocin systems (Diep et al., 2000). Down-regulation of bacteriocin production is known to occur under different environmental conditions. Changes in growth media, temperature and $\mathrm{pH}$ can induce spontaneous loss of bacteriocin production (Brurberg et al., 1997; Diep et al., 2000). Growth of Lactobacillus salivarius UCC118 in wort resulted in a $\mathrm{Bac}^{-}$phenotype; reversion to a $\mathrm{Bac}^{+}$phenotype was observed only when wort was supplemented with chemically synthesized AbpIP or with CFS. Analogous to other systems, it is likely that bacteriocin production in Lactobacillus salivarius UCC118 is controlled by an auto-induction mechanism involving the secreted pep- tide pheromone AbpIP. Further investigations are required to determine the nature of the constituent(s) in wort which affect regulation of bacteriocin production.

Lactobacillus salivarius UCC118 appears to have the genetic potential on the $10.77 \mathrm{~kb}$ EcoRI fragment to produce several other Class II bacteriocin-like peptides. It is not uncommon that identical bacteriocins are produced by different strains of the same species, or by different bacterial species belonging to the same genus (Ennahar et al., 2000). ORF3 specifies a peptide that is almost identical to presalivaricin B, a bacteriocin produced by Lactobacillus salivarius M6 (ten Brink et al., 1994). An internal deletion in the abp118 $\alpha$ gene abolished all bacteriocin production in the heterologous hosts Lactobacillus plantarum and Lactococcus lactis IL1403. This leaves the possibility that the presalivaricin-B-encoding gene is not expressed, is not processed and/or secreted, or that the single amino acid difference could have rendered the ORF3-specified peptide inactive. Similar single amino acid changes have been shown to have a profound effect on the biological activity of carnobacteriocin B2 and mesentericin Y (Fleury et al., 1996; Quadri et al., 1997).

To our knowledge, this is the first published report of a bacteriocin isolated from a probiotic strain of human origin to be purified and genetically analysed. Although the health-contributing effects of a bacteriocin-producing bacterium may be difficult to measure, it may be obvious that the ability to inhibit growth of or to kill possible pathogenic bacteria in the gastrointestinal tract will not only give this bacterium a competitive advantage within this environment but will also directly benefit the human host. Localized bacteriocin production is an important attribute of probiotic strains, enabling them to become established and to dominate their environment. In addition to the abp118 structural genes, Lactobacillus salivarius UCC118 appears to contain genetic information encoding additional bacteriocin-like peptides, which are either not bioactive or not expressed/secreted, or which do not affect the indicator strains used in this study. Future investigations on the abp118 locus are continuing and will, among other things, focus on the regulatory aspects of ABP-118 production.

\section{ACKNOWLEDGEMENTS}

We acknowledge the technical assistance of Aine Healy, Linda Walsh, Sinead Geary and Therese Uniacke of the National Food Biotechnology Centre, Cork. We express our gratitude to Bryan Dunbar, University of Aberdeen, for MS analysis. This research was supported by BioResearch Ireland.

\section{REFERENCES}

Allison, G. E., Fremaux, C. \& Klaenhammer, T. R. (1994). Expansion of bacteriocin activity and host range upon complementation of two peptides encoded within the lactacin F operon. $J$ Bacteriol 176, 2235-2241.

Altschul, S. F., Madden, T. L., Schaffer, A. A., Zhang, J., Zhang, Z., Miller, W. \& Lipman, D. J. (1997). Gapped BLAST and PSI-BLAST : a 
new generation of protein database search programs. Nucleic Acids Res 25, 3389-3402.

Anderson, D. G. \& McKay, L. L. (1983). Simple and rapid method for isolating large plasmid DNA from lactic streptococci. Appl Environ Microbiol 46, 549-552.

Aukurst, T. \& Blom, H. (1992). Transformation of Lactobacillus strains used in meat and vegetable fermentations. Food Res Int 25, 253-261.

Axelsson, L. \& Holck, A. (1995). The genes involved in production of and immunity to sakacin A, a bacteriocin from Lactobacillus sake Lb706. J Bacteriol 177, 2125-2137.

Birnboim, H. C. \& Doly, J. (1979). A rapid alkaline extraction procedure for screening recombinant plasmid DNA. Nucleic Acids Res 7, 1513-1523.

Brurberg, M. B., Nes, I. F. \& Eijsink, V. G. (1997). Pheromoneinduced production of antimicrobial peptides in Lactobacillus. Mol Microbiol 26, 347-360.

Chambers, S. P., Prior, S. E., Barstow, D. A. \& Minton, N. P. (1988). The pMTL nic-cloning vectors I. Improved pUC polylinker regions to facilitate the use of sonicated DNA for nucleotide sequencing. Gene 68, 139-149.

Cornwell, G. G. d., Sletten, K., Johansson, B. \& Westermark, P. (1988). Evidence that the amyloid fibril protein in senile systemic amyloidosis is derived from normal prealbumin. Biochem Biophys Res Commun 154, 648-653.

de Ruyter, P. G., Kuipers, O. P. \& de Vos, W. M. (1996). Controlled gene expression systems for Lactococcus lactis with the foodgrade inducer nisin. Appl Environ Microbiol 62, 3662-3667.

de Saizieu, A., Gardes, C., Flint, N., Wagner, C., Kamber, M., Mitchell, T. J., Keck, W., Amrein, K. E. \& Lange, R. (2000). Microarray-based identification of a novel Streptococcus pneumoniae regulon controlled by an autoinduced peptide. J Bacteriol 182, 4696-4703.

Diep, D. B., Håvarstein, L. S., Nissen-Meyer, J. \& Nes, I. F. (1994). The gene encoding plantaricin A, a bacteriocin from Lactobacillus plantarum $\mathrm{C} 11$, is located on the same transcription unit as an agr-like regulatory system. Appl Environ Microbiol 60, 160-166.

Diep, D. B., Axelsson, L., Grefsli, C. \& Nes, I. F. (2000). The synthesis of the bacteriocin sakacin $\mathrm{A}$ is a temperature-sensitive process regulated by a pheromone peptide through a threecomponent regulatory system. Microbiology 146, 2155-2160.

Dunne, C., Murphy, L., Flynn, S. and 12 other authors (1999). Probiotics: from myth to reality. Demonstration of functionality in animal models of disease and in human clinical trials. Antonie Leeuwenhoek 76, 279-292.

Ehrmann, M. A., Remiger, A., Eijsink, V. G. H. \& Vogel, R. F. (2000). A gene cluster encoding plantaricin 1.25 and other bacteriocin-like peptides in Lactobacillus plantarum TMW1.25. Biochim Biophys Acta 1490, 355-361.

Ennahar, S., Sashihara, T., Sonomoto, K. \& Ishizaki, A. (2000). Class IIa bacteriocins: biosynthesis, structure and activity. FEMS Microbiol Rev 24, 85-106.

Fleury, Y., Dayem, M. A., Montagne, J. J., Chaboisseau, E., Le Caer, J. P., Nicolas, P. \& Delfour, A. (1996). Covalent structure, synthesis, and structure-function studies of mesentericin $Y$ 105(37), a defensive peptide from Gram-positive bacteria Leuconostoc mesenteroides. J Biol Chem 271, 14421-14429.

Franz, C. M. A. P., van Belkum, M. J., Worobo, R. W., Vederas, J. C. \& Stiles, M. E. (2000). Characterization of the genetic locus responsible for production and immunity of carnobacteriocin A : the immunity gene confers cross-protection to enterocin B. Microbiology 146, 621-631.
Fykse, E. M., Sletten, K., Husby, G. \& Cornwell, G. G. d. (1988). The primary structure of the variable region of an immunoglobin IV light-chain amyloid-fibril protein (AL GIL). Biochem J 256, 973-980.

Guarner, F. \& Schaafsma, G. J. (1998). Probiotics. Int J Food Microbiol 39, 237-238.

Harley, C. B. \& Reynolds, R. P. (1987). Analysis of E. coli promoter sequences. Nucleic Acids Res 15, 2343-2361.

Håvarstein, L. S., Holo, H. \& Nes, I. F. (1994). The leader peptide of colicin $\mathrm{V}$ shares consensus sequences with leader peptides that are common among peptide bacteriocins produced by Gram-positive bacteria. Microbiology 140, 2383-2389.

Håvarstein, L. S., Diep, D. B. \& Nes, I. F. (1995). A family of bacteriocin $\mathrm{ABC}$ transporters carry out proteolytic processing of their substrates concomitant with export. Mol Microbiol 16, 229-240.

Håvarstein, L. S., Gaustad, P., Nes, I. F. \& Morrison, D. A. (1996). Identification of the streptococcal competence-pheromone receptor. Mol Microbiol 21, 863-869.

Holo, H. \& Nes, I. F. (1989). High-frequency transformation by electroporation of Lactococus lactis subsp. cremoris grown with glycine in osmotically stablized media. Appl Environ Microbiol 55, 3119-3123.

Horton, R. M., Cai, Z. L., Ho, S. N. \& Pease, L. R. (1990). Gene splicing by overlap extension: tailor-made genes using the polymerase chain reaction. Biotechniques 8, 528-535.

Klaenhammer, T. R. (1993). Genetics of bacteriocins produced by lactic acid bacteria. FEMS Microbiol Rev 12, 39-85.

Kleerebezem, M., Quadri, L. E., Kuipers, O. P. \& de Vos, W. M. (1997). Quorum sensing by peptide pheromones and twocomponent signal-transduction systems in Gram-positive bacteria. Mol Microbiol 24, 895-904.

Marciset, O., Jeronimus-Stratingh, M. C., Mollet, B. \& Poolman, B. (1997). Thermophilin 13, a nontypical antilisterial poration complex bacteriocin, that functions without a receptor. J Biol Chem 272, 14277-14284.

Mattila-Sandholm, T., Mättö, J. \& Saarela, M. (1999). Lactic acid bacteria with health claims - interactions and interference with gastrointestinal flora. Int Dairy J 9, 25-35.

Mayr-Harting, A., Hedges, A. J. \& Buckley, R. C. W. (1972). Methods for Studying Bacteriocins. New York: Academic Press.

McCormick, J. K., Poon, A., Sailer, M., Gao, Y., Roy, K. L., McMullen, L. M., Vederas, J. C., Stiles, M. E. \& van Belkum, M. J. (1998). Genetic characterization and heterologous expression of brochocin-C, an antibotulinal, two-peptide bacteriocin produced by Brochothrix campestris ATCC 43754. Appl Environ Microbiol 64, 4757-4766.

McGrath, S., Fitzgerald, G. F. \& van Sinderen, D. (2001). Improvement and optimization of two engineered phage-resistance mechanisms in Lactococcus lactis. Appl Environ Microbiol 67, 608-616.

Naidu, A. S., Bidlack, W. R. \& Clemens, R. A. (1999). Probiotic spectra of lactic acid bacteria (LAB). Crit Rev Food Sci Nutr 39, 13-126.

Nes, I. F. \& Eijsink, V. G. H. (1999). Regulation of group II peptide bacteriocin synthesis by quorum-sensing mechanisms. In CellCell Signaling in Bacteria, pp. 175-192. Edited by G. M. Dunny and S. C. Winans. Washington, DC: American Society for Microbiology.

Nes, I. F., Diep, D. B., Håvarstein, L. S., Brurberg, M. B., Eijsink, V. \& Holo, H. (1996). Biosynthesis of bacteriocins in lactic acid bacteria. Antonie Leeuwenhoek 70, 113-128. 
Nissen-Meyer, J., Holo, H., Håvarstein, L. S., Sletten, K. \& Nes, I. F. (1992). A novel lactococcal bacteriocin whose activity depends on the complementary action of two peptides. J Bacteriol 174, 5686-5692.

O'Keeffe, T., Hill, C. \& Ross, R. P. (1999). Characterization and heterologous expression of the genes encoding enterocin A production, immunity, and regulation in Enterococcus faecium DPC1146. Appl Environ Microbiol 65, 1506-1515.

Parente, E. \& Hill, C. (1992). A comparision of factors affecting the production of two bacteriocins from lactic acid bacteria. J Appl Bacteriol 73, 290-298.

Park, S. F. \& Stewart, G. S. A. B. (1990). High-efficiency transformation of Listeria monocytogenes by electroporation of penicillin treated cells. Gene 94, 129-132.

Pospiech, A. \& Neumann, B. (1995). A versatile quick preparation of genomic DNA from Gram positive bacteria. Trends Genet 11, 217-218.

Quadri, L. E., Yan, L. Z., Stiles, M. E. \& Vederas, J. C. (1997). Effect of amino acid substitutions on the activity of carnobacteriocin B2. Overproduction of the antimicrobial peptide, its engineered variants, and its precursor in Escherichia coli. J Biol Chem 272, 3384-3388.

Sambrook, J., Fritsch, E. F. \& Maniatis, T. (1989). Molecular Cloning: a Laboratory Manual, 2nd edn. Cold Spring Harbor, NY: Cold Spring Harbor Laboratory.

Schurter, W., Geiser, M. \& Mathe, D. (1989). Efficient transformation of Bacillus thuringiensis and B. cereus via electropora- tion: transformation of acrystalliferous strains with a cloned delta-endotoxin gene. Mol Gen Genet 218, 177-181.

Simon, D. \& Chopin, A. (1988). Construction of a vector plasmid family and its use for molecular cloning in Streptococcus lactis. Biochimie 70, 559-566.

ten Brink, B., Minekus, M., van der Vossen, J. M., Leer, R. J. \& Huis in't Veld, J. H. (1994). Antimicrobial activity of lactobacilli: preliminary characterization and optimisation of production of acidocin B, a novel bacteriocin produced by Lactobacillus acidophilus M46. J Appl Bacteriol 77, 140-148.

Tinoco, I., Jr, Borer, P. N., Dengler, B., Levin, M. D., Uhlenbeck, O. C., Crothers, D. M. \& Bralla, J. (1973). Improved estimation of secondary structure in ribonucleic acids. Nat New Biol 246, $40-41$.

Venema, K., Dost, M. H., Beun, P. A., Haandrikman, A. J., Venema, G. \& Kok, J. (1996). The genes for secretion and maturation of lactococcins are located on the chromosome of Lactococcus lactis IL1403. Appl Environ Microbiol 62, 16891692.

Yanisch-Perron, C., Vieira, J. \& Messing, J. (1985). Improved M13 phage cloning vectors and host strains: nucleotide sequences of the M13mp18 and pUC19 vectors. Gene 33, 103-119.

Received 20 August 2001; revised 28 November 2001; accepted 10 December 2001 